\title{
POLITICAL CONFLICT AND INVESTMENT INFLOWS INTO ACEH PROVINCE OF INDONESIA
}

\author{
Azhari Yahya \\ Faculty of Law, Syiah Kuala University \\ Banda Aceh, Indonesia \\ e-mail: azhari.yahya@unsyiah.ac.id
}

\begin{abstract}
.
This paper aims to scrutinize a correlation between political conflict and investment inflows into Aceh Province. In conducting this study, researcher applied qualitative research method by relying on ssecondary data. These were obtained through library research by analyzing relevant documents, government reports, case studies and current literature. The results indicate that investment inflows into Aceh Province during political conflict period between the Free Aceh Movement and Indonesia central ggovernment were totally low due to unsecured condition that occur in this province. Unsecured political condition made investors feel reluctant to invest their capital in this province because they do not want to lose their capital by investing in high risk investment area. Therefore, during this political conflict period (1976-2005) Aceh was not considered as one of investment destinations in Indonesia. Fortunately, better investment condition in Aceh is achieved after Indonesian central government and the Free Aceh Movement agreed to seek a peaceful conflict resolution through a peaceful agreement which was signed by both parties on $15^{\text {th }}$ August 2005 in Helsinki. Since that time the amount of investment inflows into Aceh has signficantly increased due to stable political condition. It is suggested that the government should maintain stable political condition to attract more investment inflows into Aceh Province in the future.
\end{abstract}

Key words: Political Conflict, Investment Inflows.

\section{INTRODUCTION}

Aceh is a province of Indonesia located on the Island of Sumatra in the western part of Indonesia. The province which is inhabited by 5 million people is known as one of rich natural resources province especially in oil and gas sector. The resource wealth of Aceh makes it into one of Indonesia's most important locations for investment either domestic or foreign investment. The province which has very low population density has supplied enormous wealth to the Central Government of Indonesia extracted from natural resources especially oil and gas. Aceh's main income earners are oil, natural gas, gold, coal, limestone, timber, iron, fertilizer, rice, coffee, cocoa, coconut, corn, pepper, sugar cane and tobacco. Around $85 \%$ of the total Acehnese population (4.5 million) work in agriculture, while the rest work in various sectors such as trading, industry and paid labour and civil servant for their main livelihood.

For the last 30 years, Aceh has been torn by a separatist political conflict waged by the Free Aceh Movement against Jakarta rooted in issues over control of natural resources, economic system of Indonesian central government and historical as well as legal issues over the transfer of Aceh region to Indonesia by the Dutch [1]. During 1970s, under the agreement with Indonesian central government, American oil and gas company began exploitation of Aceh natural resources. Alleged unequal distribution of profit between central government and native people of Aceh induced Hasan di Tiro to call for Independent of Aceh. He proclaimed Aceh Independence on 4th December 1976. During late 1980s several security incidents prompted the Indonesian central government to take repressive measures and to send troops to Aceh [2]. Consequently human rights abuse was rampant everywhere resulting in many grievances on the part of Acehnese toward Indonesian central government.

The 2004 tsunami helped trigger a peace agreement between the Free Aceh Movement and Indonesian central government. It drew a lot of international attention to the conflict, wiped out many supplies, and killed many personnel from both sides [3]. Earlier efforts to resolve this political conflict had failed, but for a number of reasons including the tsunami, peace prevailed in 2005 after 29 years of war. Post-Suharto era and the liberaldemocratic reform period, as well as changes in the Indonesian military, helped create an environment more favorable to peace talks. Aceh has been granted broader autonomy through Aceh Government Legislation covering special rights agreed upon in 2006 as well as the right of the Acehnese to establish local political parties to represent their interests.

In order to accelerate development in this province, the government of Indonesia opens the door for investors to invest in this province. The largest investor in Aceh at that time was the U.S 
owned Exxon Mobil Company followed by Arun LNG Company. Both international companies have been operating in the North Aceh District since 1970s. From that time onwards, Aceh became one of the important Indonesia's generators of national revenues resulted from investment project in oil and gas sector [4]. At the beginning Aceh was quite happy with this type of investment that resulted in huge revenues and at that time all people expected that more investment would be invested in Aceh to follow Exxon Mobil Company and Arun LNG Company. However, the fact show that the number of investment inflows into Aceh was sharply dropped after political conflict between the Aceh Free Movement and Central Governement occured in 1976.

In line with the above condition this paper is aimed to explore a correlation between conflict and investment inflows into Aceh Province. This study will also answer a question to what extent political conflict may influence investment inflows into Aceh Province.

\section{INVESTMENT INFLOWS INTO ACEH}

The Acehnese, like many populations in the modern Republic of Indonesia, are ethnically distinct from the large populations of Java. They speak a different language, and furthermore, consider themselves to have a distinct and proud history. For example, the province refers to itself as the 'verandah of Mecca,' a label which conveys its geographical distinction of being the closest Indonesian province to the holy land of Islam, but also its distinct history of religious education, government and piety [5].

Aceh has been open to investment since 1967 when the government of Indonesia passed the Act Number 1 of 1967 on Foreign Direct Investment. Since then many foreign investors have come to explore the natural resources in this province. After quick exploration, some foreign companies began to invest their capital in this province - especially in oil, gas, timber and agricultural sectors. Investment inflows into Aceh are fluctuated all the times. It is hard to keep steady flows of investment into this province due to fluctuation of its social and political condition all the times.

Investement inflows into Aceh have fluctuated dramatically during political conflict period between 1968 and 2005. One of the main factors behind these fluctuations was the tragic political conflict between Aceh Free Movement and the central government of Indonesia. The Aceh Free Movement insurgency was the defining characteristic of Aceh from 1968 to 2005. However, problems arose because of the profit-sharing arrangement between Aceh and the central government [6]. At that time, under the Soeharto regime, the profit-sharing system from such natural resources exploitation specified that all profits should go to Jakarta first. In a second step, the central government would then redistribute these profits to all provinces equally based on population [7].

As a result, Aceh which had a very low population, only received a very small portion from the 'big oil cake' when compared with the portion received by the other provinces in Java Island, a more densely populated region. This condition created a sense of locality-based injustice amongst the Acehnese people. As they saw it, resources from the region were being sold for the benefit of people elsewhere in Indonesia. It describes how the Exxon project caused protests to arise in Aceh. Events took a tragic turn when the protests turned into an ethnic separatist movement [8].

After a long negotiation process this conflict ended through a peace agreement process known as the Helsinki Accord, which was signed between the Indonesian government and the Free Aceh Movement in Helsinki on $15^{\text {th }}$ August 2005. The conflict had been a long and bloody one (perhaps up to 15,000 people were killed), and has left many traces in contemporary Aceh [9]. The civil strife had a significant negative impact on inward flow of investment into Aceh. The facts show that after 1968, the year in which foreign investment first came to Aceh, there was no more foreign investment in that province until 1979. From 1979, foreign investors remained uncertain about the security of their investments, with the result that years of large inflows oscillated with years of small or no inflows.

When investment inflows increased, they were frequently in response to government incentives. For example, in 1980-1981 some foreign investment returned to Aceh after the governor of Aceh guaranteed the security of foreign companies. This was the time that the Lafarge Group from France began to invest in Aceh in order to produce cement for domestic use and export. Typically, the modest revival of investment then collapsed, largely owing to the conflict between the separatist movement and the Indonesian army.

Despite the sporadic violence created by the separatist conflict, investment inflows into Aceh starts to rise after better political condition in Aceh as a whole. This condition also support the study conducted by Chen showing that better political condition in the host country may attract more inward investment[10]. Similarly this finding is also in line what has been studied by Gerlach \& Yook 
[11]; Wu \& Heerrink [12], Franke \& Oztrurk [13], Gomes [14] and Lacomba et al [15]. All these studies agree that investment inflows have a strong correlation with political conflict in the host country.

\section{POLITICAL CONFLICT AND INVESTMENT INFLOWS}

Since investment reaches Aceh, this province has generated significant wealth for Indonesia due to Aceh has huge oil and gas reserve. By having significant amount of investment inflows is expected that social and economic life of Acehnese community especially who are living around foreign companies would be better off. However, development process in this province has been highly problematic and given rise to many social problems such as poverty, social economic gap, social conflict, social jealousy, political tension, and human rights abuse [16].

Furthermore, the facts indicate that there are several critical issues have been associated with the extraction of natural resources in Aceh Province especially oil and gas. Some local people argue that to some extents investment is undermining their employment opportunities. Most employees working in foreign companies are imported from other provinces and some expertises are also imported from other countries. This condition has resulted in horizontal conflict between companies and local people. In addition, unequal distribution of wealth extracted from Aceh between Indonesian central government and Aceh government has also caused vertical political tension between both of them. Consequently, injustice of wealth distribution has led community in Aceh lives under poverty line. On one hand Aceh produces enormous wealth; on the other hand it faces serious poverty problem. This condition is considered as an embryo of political conflict between Aceh Free Movement and Indonesian central government to get more wealth for Acehnese people [17].

This conflict present serious threats to national harmony and social cohesion in Indonesia. Initially a conflict in local communities starts from a misunderstanding between local people and foreign companies operating in their area. Misunderstanding abounds on matters such as the objective of invesetment and how investment works. Misunderstanding can quickly escalate into civil strife. In some cases the misunderstanding is based on a conflict between local communities and the government that has allowed and facilitated the investment operation. In such cases, civil strife might escalate into an insurgency movement.
A dramatic example for this case is Freeport's Mt Ertsberg Mining Company in West Papua Province. The Mt Ertsberg mine is the second largest copper mine in the world, and also has the largest proven gold deposit. Despite this natural wealth, the Province has experienced ongoing tensions between government security forces and separatists, as well as more widespread popular discontent with the Indonesian government. The foreign company has been extracting natural resources in this province - mainly gold, copper and silver. During that time, inequality between employed and unemployed Papuan workers has increased. Greater income disparities between West Papua Province and Java, for example, have also increased. Income disparities of this kind were unheard before the foreign investors arrived.

This foreign company has earned not less than $\$ 100$ billion from the extraction of West Papua's mineral resources. At least 1,448 tonnes of gold, not to mention vast amounts of copper and silver, have been scraped out of Mt Ertzberg. Prior to the establishment of the mining company, Mt Ertzberg was communally owned by a West Papuan tribe, and the area served as a traditional hunting ground. Now, the local communities who previously occupied this area had to move to other areas that might not be as conducive to their way of life. These complaints compound a deep resentment about the fact that the local communities have not had a share of the profits made from the resources extracted from their own land. Local communities are demanding a bigger share of the investment cake, and threaten to have the mine shut down otherwise [18].

Similar political conflict related to investment also arose in Aceh in 1976-2005 after the US-owned Exxon Mobil Company started its oil and gas exploration in North Aceh in 1971. As happened in the case of the Papuan mine described above, the Acehnese communities also wanted a bigger share of the profits earned by the foreign firm that was extracting the natural resources of their area. Again, as happened in the Papuan case, local people established an organisation called the Aceh Free movement to address the problem of a fairer distribution of profits. Local villages expected that Aceh Free Movement would help them to seal a better deal with the foreign company, but things turned out differently.

The final stand was taken on $4^{\text {th }}$ December 1976 when Aceh Free Movement wanted its independence from Indonesia. Initially the conflict took place in the jungle with few casualties, over time it became more bloody and intruded on the lives of civilians. In responding this conflict, the 
Indonesian central government declared a military operations zone in Aceh and this operation remained so for almost 10 years, during which time people's day-to-day lives were characterized by sporadic yet intense violence, political uncertainty and economic hardship. In order to overcome this political conflict the Indonesian central government set up a dialogue with the Aceh Free Movement to sign a Cessation of Hostilities Agreement in December 2002. But by May 2003 that agreement had broken down and the Government of Indonesia declared martial law in Aceh that remained in place for the next three years.

The conflict did not end until $15^{\text {th }}$ August 2005 when a peace accord was signed in Helsinki by both Indonesian central government and the Free Aceh Movement. Finally from $15^{\text {th }}$ August 2005 onward political condition in Aceh has been stable and investors start to consider Aceh Province as one of investment destination in Indonesia. Then starting from 2006 onward investment from overseas and domestic are steadily invested in Aceh after better political condition has been achieved.

\section{CONCLUSION}

This study concludes that political conflict has significant correlation with investment inflows into Aceh Province. This condition can be seen from the total amount of investment which was invested in this province during political conflict period was totally low. This conflict had diterminated willingness of investors who wish to invest their capital in this region due to unscured political condition. Economically unsecured political condition might cause significant loss of investment and none investor wants to take this investment risk. Therefore, it is quite logic if during this political conflict period many investorts reluctant to consider Aceh as their investment destination except investors whose project related to natural resources sector such as oil and gas. These types of investement are almost free from any disturbance because their operation area is off shore; while the other type of investment was hard to be implemented. The facts also show that there was very few investment outside oil and gas sector was invested in Aceh during political conflict period either by foreign and domestic investors. These facts support a finding that political condition becomes one of important diterminants for investment inflows into Aceh Province. Therefore, it is suggested that the government should maintain better political condition to attract more inward investment in the future.

\section{REFERENCES}

[1] Aspinall, E 2007, "Violence and identity formation in Aceh under Indonesian rule" in Anthony Reid (ed) Verandah of violence: The background to the Aceh problem, NUS Press, Singapore, pp. 149-176.

[2] Aspinall, E 2008, "Place the Displacement in the Aceh Conflict", in Eva-Lotta Hedman (ed.), Conflict, Violence, and Displacement in Indonesia, Cornell University, USA, pp. 55-65.

[3] Ford, M \& Dibley, T 2011, "Developing a movement? Aid-based mediated diffusion as a strategy labour activism in post-tsunami Aceh", Asian Journal of Social Science, Vol. 39, pp. 469-488.

[4] Barron, P \& Burke, A 2008, Supporting peace in Aceh: Development agencies and international involvement, East-West Center, Washington DC

[5] Aspinall, E 2009, Islam and Nation: Separatist Rebellion in Aceh, Indonesia, Stanford University Press, Stanford USA.

[6] Kingsbury, D 2010, "The Aceh peace process", in Arndt Graf, Susanne Schroter \& Edwin Wieringa (eds), Aceh: History, Politics and Culture, ISEAS Publishing, Singapore, pp 135156.

[7] Jaya, W K 2007, An institutional approach to fiscal decentralization in Indonesia: An assessment of the regional autonomy reforms between 1999 and 2004, PhD Thesis, Monash University.

[8] George, K M 2010, "Picturing Aceh: Violence, religion and painter's tales" in Arndt Graf, Susanne Schroter \& Edwin Wieringa (eds), Aceh: History, Politics and Culture, ISEAS Publishing, Singapore, pp. 243-264.

[9] Ziegenhain, P 2010, "The Aceh conflict during the new order and the following democraticzation process" in in Arndt Graf, Susanne Schroter, Edwin Wieringa (eds), Aceh: History, Politics and Culture, ISEAS Publishing, Singapore, pp.120-134.

[10] Chen, C 2003, "Location determinants and provincial distribution of FDI", in Ross

Garnaut \& Ligang Song (eds), China new engine of world growth, Asia Pacific Press, Australian National University, Canberra, Australia

[11] Gerlach, J \& Yook, Y 2016, "Political conflict and foreign portfolio investment: Evidence from North Korean attacks", Pacific-Basin Finance Journal Vol. 39, pp.178-196. 
[12] Wu, Y \& Heerrink, N 2016, "Foreign direct investment, fiscal decentralization and land conflicts in China", China Economic Review Vol 38, pp. 92-107.

[13] Franke, J \& Ozturk, T 2015, "Conflict Network", Journal of Public Economics Vol. 126, pp. 104-113

[14] Gomes, J 2017, "Comment on partisan conflict and private investment", Journal of Monetary Economics 000 pp. 1-3.

[15] Lacomba, J A et al 2017, "Decisiveness, peace, and inequality in games of conflict", Journal of Economic Psychology Vol. 63, pp. 216229.

[16] Braithwaite, J et al 2010, Anomie and violence: Non-truth and reconciliation in Indonesian peace building, ANU E-Press, ANU Canberra.

[17] Kingsbury, D 2010, "The Aceh peace process", in Arndt Graf, Susanne Schroter \& Edwin Wieringa (eds), Aceh: History, Politics and Culture, ISEAS Publishing, Singapore, pp 135-156.

[18] Trajano, J I 2010, "Ethnic nationalism and separatism in West Papua, Indonesia", Journal of Peace, Conflict and Development, Vol. 16, pp. 12-35. 